\title{
Anchitheriinae (Perissodactyla, Equidae) from the early middle Miocene locality Gračanica (Bugojno Basin, Bosnia-Herzegovina)
}

\author{
Damien Becker $^{1,2}$ [D. Jérémy Tissier ${ }^{1,2}$ (D). Davit Vasilyan ${ }^{1,2}$ (D). Ursula B. Göhlich ${ }^{3}$ (D)
}

\begin{abstract}
The early middle Miocene (European Land Mammal Zone MN5-earliest MN6) locality Gračanica (Bugojno Basin, BosniaHerzegovina) has yielded numerous well-preserved dental remains of two Anchitheriinae species: Anchitherium hippoides and Anchitherium ezquerrae. This anchithere assemblage is typical of the Orleanian European Land Mammal Age and is recorded for the first time in Southeastern Europe.
\end{abstract}

Keywords Anchitherium · Middle Miocene $\cdot$ Southeastern Europe $\cdot$ Bosnia-Herzegovina

$\begin{array}{ll}\text { Abbreviations } \\ \text { I/i } & \text { Upper/lower incisor } \\ \mathrm{M} / \mathrm{m} & \text { Upper/lower molar } \\ \mathrm{P} / \mathrm{p} & \text { Upper/lower premolar } \\ \mathrm{APD} & \text { Antero-posterior diameter } \\ \mathrm{art} & \text { Articular } \\ \mathrm{dist} & \text { Distal } \\ \mathrm{H} & \text { Height } \\ \mathrm{L} & \text { Length } \\ \mathrm{max} & \text { Maximum } \\ \mathrm{min} & \text { Minimum } \\ \mathrm{prox} & \text { Proximal } \\ \mathrm{TD} & \text { Transverse diameter } \\ \mathrm{W} & \text { Width } \\ \mathrm{MCZ} & \text { Museum of Comparative Zoology, } \\ & \text { Cambridge, USA } \\ \text { MNHN } & \text { Muséum national d'Histoire naturelle, } \\ & \text { Paris, France }\end{array}$

This article is a contribution to the special issue "The drowning swamp of Gračanica (Bosnia-Herzegovina)- a diversity hotspot from the middle Miocene in the Bugojno Basin."

Ursula B. Göhlich

ursula.goehlich@nhm-wien.ac.at

1 Jurassica Museum, Route de Fontenais 21, 2900 Porrentruy, Switzerland

2 Earth Sciences, University of Fribourg, Chemin du Musée 6, 1700 Fribourg, Switzerland

3 Department of Geology and Paleontology, Natural History Museum Vienna, Burgring 7, 1010 Vienna, Austria
MJSN JURASSICA Museum (formerly Musée jurassien des sciences naturelles), Switzerland

NHMW Naturhistorisches Museum Wien, Austria

NMB Naturhistorisches Museum Basel, Switzerland

\section{Introduction}

The Gračanica locality is a coal mine situated about $10 \mathrm{~km}$ SSE from the city of Bugojno in central Bosnia and Herzegovina. It belongs to the Bugojno Basin, a large intramountain basin in the Dinarides (Mandic et al. 2016; Mandic et al. in prep., this issue) (Fig. 1). The outcropped sedimentary record of Gračanica locality is about $40 \mathrm{~m}$ thick (Mandic et al. 2016). It is divided in a lower series of dark lignite deposits (unit 1) and an upper one of laminated light-coloured fine lacustrine sediments (units 2 and 3) (Fig. 2). Due to mining activities in 2019, a package of brownish-yellowish clays containing some mammalian fossils has been exposed in the south-eastern upper part of the quarry. However, its stratigraphic position in relation to the main section (unit 1-3) is unclear so far due to any missing contact of this sediment package to the excavation front. A huge quantity of mammal remains are preserved in the lignite-bearing part of the section (unit 1) (e.g. Mandic et al. 2016; Becker and Tissier in press, this issue; Aiglstorfer and Mayda, in press, this issue; Bastl et al. in press, this issue; Coombs and Göhlich, in press, this issue; Göhlich in press, this issue; Stefen in press, this issue; Wessels et al. in press, this issue), inherited from a swampy 


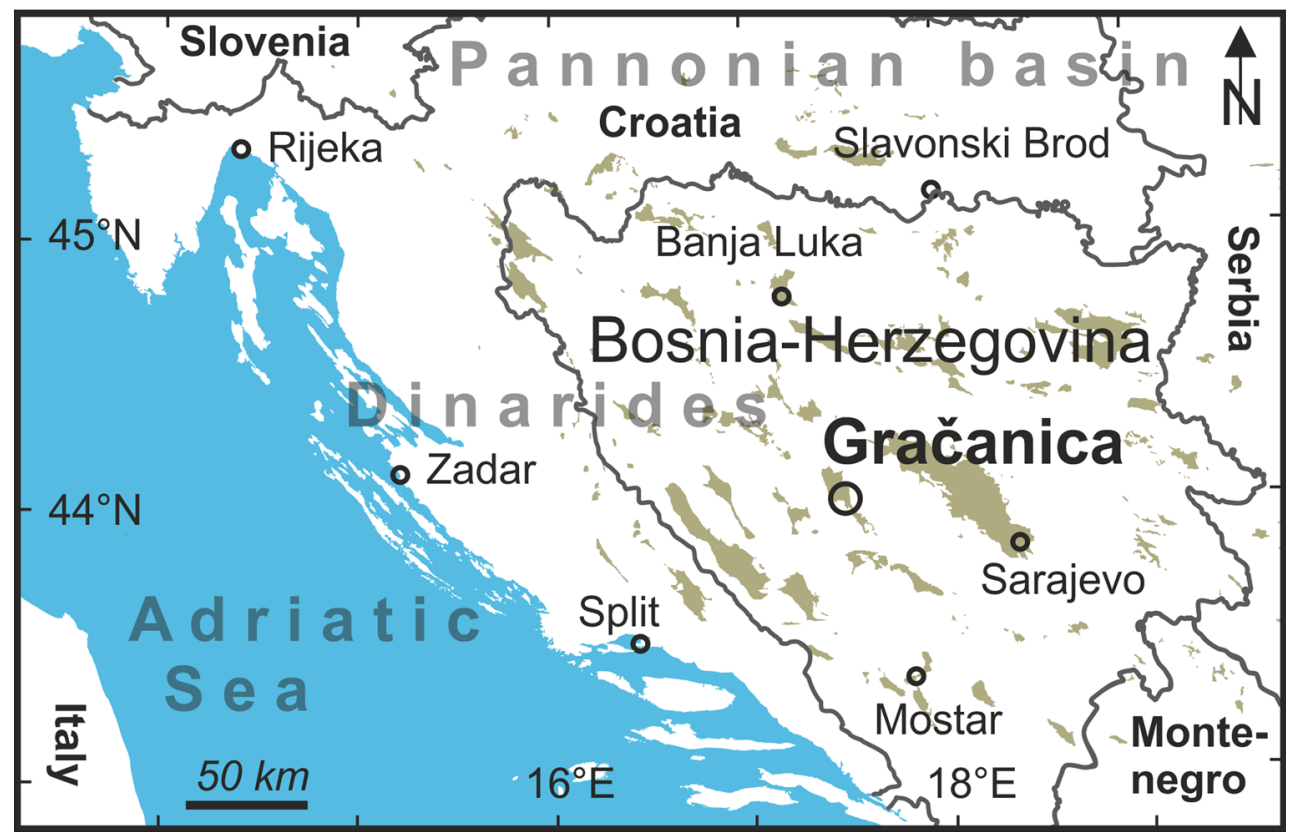

Fig. 1 Geographical setting of the locality Gračanica in Bosnia and Herzegovina with indication of Neogene basins in the Dinarides (in dark green colour), after Mandic et al. $(2012,2016)$

environment, whereas the upper lacustrine series (units 2 and 3) provides remains of invertebrates (e.g. Harzhauser et al. in press, this issue; Hyžný in press, this issue; Wedmann and Skartveit in press, this issue) and ectothermic vertebrates (Vasilyan in press, this issue). The recently exposed outcrop without a clear stratigraphic position yielded some new dental remains.

From ongoing magnetostratigraphic analyses, the age of the deposits is somewhere in the range between 15.2 and 14.0 Ma, correlating with MN5 and earliest MN6 (Mandic et al. in prep., this issue). This result is congruent with the MN5 age based on molluscs and small mammalian fauna (Harzhauser et al. in press, this issue; Wessels et al. in press, this issue). We consider the new exposed package not significantly different in age from the unit 1 since both anchithere species found from these layers are identical.

The Anchitheriinae is an extinct subfamily of Equidae (Perissodactyla) originated from North America. They are three-toed horses characterised by brachyodont and lophodont cheek teeth without cement. They are globally considered as browsers that occupied forested habitats (e.g. Forsten 1991; MacFadden 1992, 1998). However, Kaiser (2009) argues that Anchitherium aurelianense from Sandelzhausen (early/middle Miocene, MN5, Germany) could have been a "dirty" browser or a mixed feeder of a mosaic environment including marsh, fen, peatland, forests and open water. The large-sized genera Hypohippus and Megahippus and the medium-sized Kalobatippus are exclusively known from the Miocene faunas of North America (MacFadden 1998), whereas the dispersal of the medium-sized Anchitherium through the Bering Strait into Eurasia occurs in the early Miocene (MN3) and could be associated with the timing of a global sea-level fall around 19.5 Ma (e.g. Abusch-Siewert 1983; MacFadden 1992, 2001; Woodburne and Swisher 1995; Steininger 1999; Daxner-Höck and Bernor 2009). This genus is the most common Anchitheriinae in the mid-Miocene of Europe, displaying a great diversity of species, and became extinct in the basal late Miocene (MN9, ca. 11.0 Ma) after a short coexistence with the hipparionine horse Hippotherium primigenium (e.g. Tleuberdina and Forsten 2001; DaxnerHöck and Bernor 2009; Rotgers et al. 2011). During the early late Miocene of Europe (MN9-10; Iberian Peninsula, France, Turkey), the large-sized Asian Anchitheriinae Sinohippus co-occured with the last representatives of Anchitherium and H. primigenium (Salesa et al. 2004).

In this study, the Anchitherium remains from the Gračanica locality are described and identified as A. hippoides and A. ezquerrae. The main amount of the studied material comes from the unit 1 . Several teeth have been recently found in an outcrop without a clear stratigraphic correlation with the main section. This Anchitheriinae assemblage provides a new palaeoenvironmental interpretation of the lower lignitebearing part (unit 1) of the Gračanica section.

Fig. 2 Simplified log of the Gračanica section (Bugojno palaeolake), redrawn after Mandic et al. (2016), as well as the photo (taken in August 2019) of the quarry with the indications of the unit boundaries as well as occurrence of Anchitherium (with horse icons) 


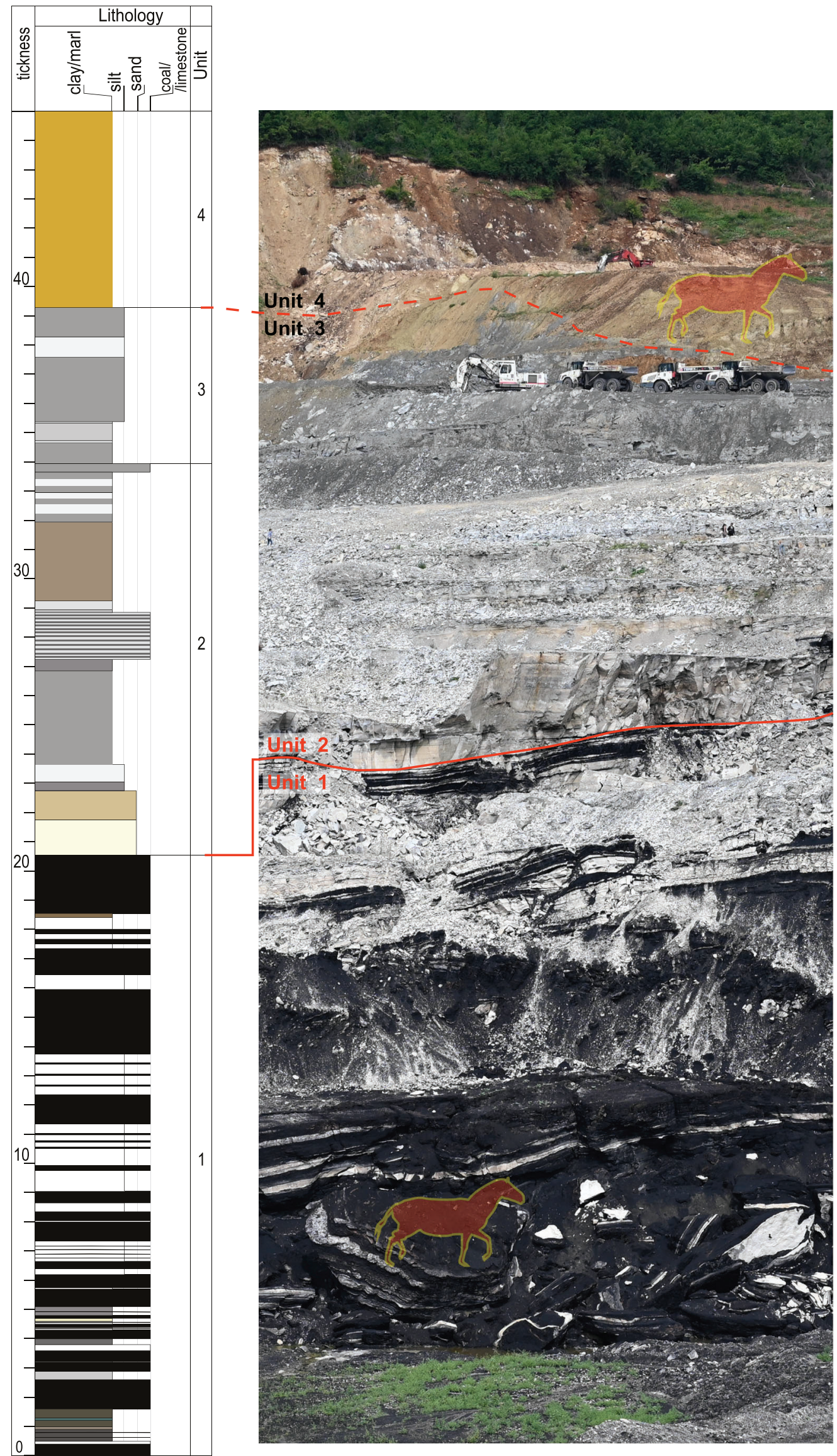

